\title{
Rapid diagnosis of Campylobacter jejuni by stool Gram stain examination
}

\author{
Kazuhiro Kamata, ${ }^{1}$ Yasuharu Tokuda ${ }^{2}$
}

${ }^{1}$ Mito Kyodo General Hospital, Mito City, Japan

${ }^{2}$ Department of General Internal Medicine, Tsukuba University, Mito, Ibaraki, Japan

\section{Correspondence to} Professor Yasuharu Tokuda, yasuharu.tokuda@gmail.com
CrossMark

To cite: Kamata $K_{\text {, }}$ Tokuda Y. BMJ Case Rep Published online: [please include Day Month Year] doi:10.1136/bcr-2013-

202876

\section{DESCRIPTION}

Microscopic stool examination by Gram stain is useful for rapid diagnosis and treatment of Campylobacter infection in patients with acute onset diarrhoea. A 69-year-old Japanese woman with pernicious anaemia presented with a 3-day history of fever and watery diarrhoea. On examination, her mental status was normal and general appearance was not in acute distress. Blood pressure was $115 / 43 \mathrm{~mm} \mathrm{Hg}$, pulse rate $131 \mathrm{bpm}$ and regular, respiration rate 20 breaths/min and temperature $39^{\circ} \mathrm{C}$. The palpebral conjunctivae were anaemic and tongue surface was atrophic and dry. Cardiovascular and lung examinations revealed no abnormality except for tachycardia. Abdominal examination revealed normal bowel sounds and mild tenderness on the right lower quadrant without rebound tenderness. Laboratory data showed elevated leucocyte count and macrocytic anaemia. The faecal Gram stain examination revealed numerous Gram-negative rods of gullwinged form (figure 1). Oral erythromycin was prescribed based on a diagnosis of Campylobacter

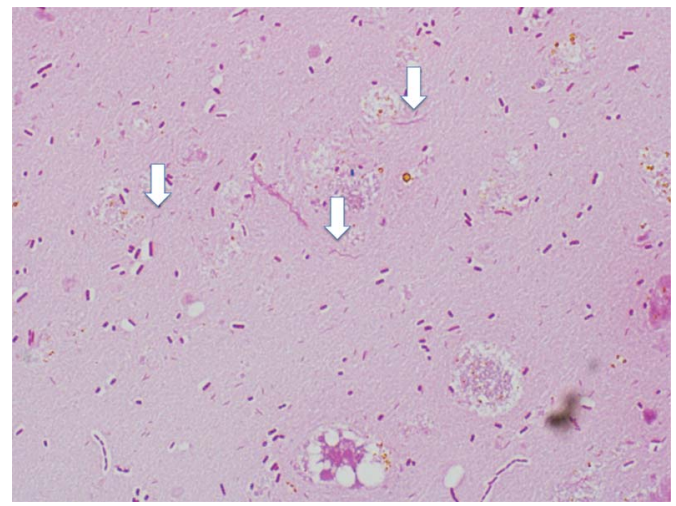

Figure 1 White arrow indicates gull-wing-shaped Gram-negative rods. enteritis. Two days after the first visit, her symptoms were improved and the stool culture grew Campylobacter jejuni. Campylobacter species are a frequent cause of infectious enteritis. Although its definitive diagnosis requires culture results, the stool Gram stain finding of gull-wing-shaped Gram-negative rods has good sensitivity and specificity. ${ }^{1}{ }^{2}$ The Gram stain examination has low cost and provides real-time diagnosis that can lead to immediate and appropriate treatment.

\section{Learning points}

Stool Gram stain examination leads to timely diagnosis and treatment of Campylobacter infection in patients with acute onset diarrhoea.

- Gram stain examination is a precious and inexpensive tool for managing common infectious diseases.

- The presence of Gram negative rods with gullwing shape in stools of diarrhoea patients suggests Campylobactor jejuni enteritis.

Contributors $\mathrm{YT}$ cared the patient and $\mathrm{YT}$ and $\mathrm{KK}$ wrote the manuscript.

Competing interests None.

Patient consent Obtained.

Provenance and peer review Not commissioned; externally peer reviewed.

\section{REFERENCES}

1 Park $\mathrm{CH}$, Hixon DL, Polhemus AS, et al. A rapid diagnosis of Campylobacter enteritis by direct smear examination. Am J Clin Pathol 1983;80:388-90.

2 Wang $H$, Murdoch DR. Detection of Campylobacter species in faecal samples by direct Gram stain microscopy. Pathology 2004;36:343-4.

Copyright 2014 BMJ Publishing Group. All rights reserved. For permission to reuse any of this content visit http://group.bmj.com/group/rights-licensing/permissions.

BMJ Case Report Fellows may re-use this article for personal use and teaching without any further permission.

Become a Fellow of BMJ Case Reports today and you can:

- Submit as many cases as you like

- Enjoy fast sympathetic peer review and rapid publication of accepted articles

- Access all the published articles

- Re-use any of the published material for personal use and teaching without further permission

For information on Institutional Fellowships contact consortiasales@bmjgroup.com

Visit casereports.bmj.com for more articles like this and to become a Fellow 